\title{
BANCASSURANCE IN THE INSURANCE DISTRIBUTION
}

\section{Tetiana Motashko ${ }^{1}$}

DOI: https://doi.org/10.30525/978-9934-26-050-6-35

Bancassurance is one of the distribution channels for insurance products. At the same time, organization of the sales system of insurance products via an extensive system of banking units has become especially popular in the field of life insurance.

Europeisthe largest market for bancassurance on a regional scale. The growth of premiums collected through such a distribution channel as bancassurance in Europe over the past decade has outpaced the growth of other distribution channels. Among the largest European life insurance

\footnotetext{
${ }^{1}$ Taras Shevchenko National University of Kyiv, Ukraine
} 
markets, most products were sold through bancassurance in Italy (76.3\%), Spain (67.5\%) and France (64\%). Malta (84.3\%), Turkey (81.5\%) and Portugal (79.3\%) were the other European markets with the most dominant bancassurance [1]. Despite this, the potential for the development of bancassurance is still quite large, especially for non-life insurance (Figure 1).

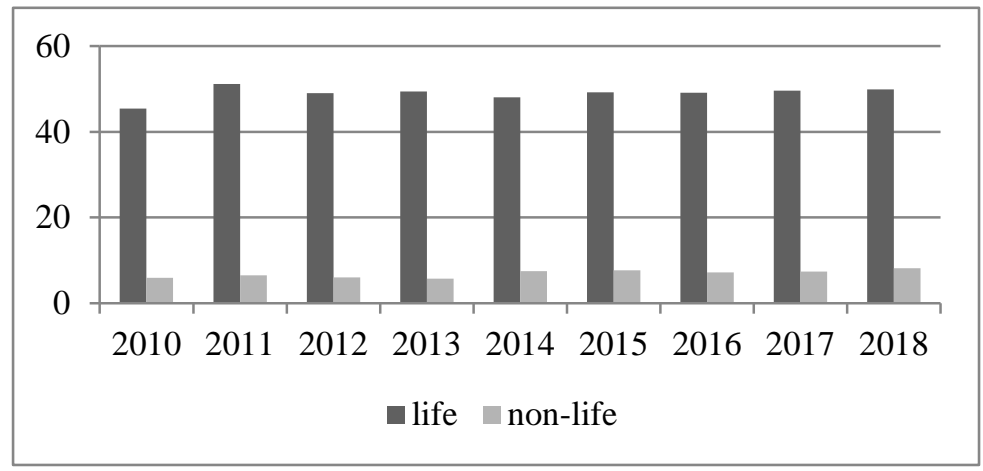

Figure 1. The share of bancassurance in the distribution of insurance products in European countries in 2010-2018, \%

Source: developed by the author according to [1]

It is worth noting that bancassurance channel turns the bank into a financial supermarket, where customers can get a wide range of credit investment and insurance services in one place in minimal time.

In general, the positive aspects of the implementation of bancassurance are embodied in three aspects:

- financial (reduction of conditionally fixed and conditionally variable costs);

- operating (simplification of technological processes, access to technologies and developments of the partner);

- marketing (development of new products, increasing market share, geographical diversification) [2, p. 261].

However, despite the significant role of such a channel in the distribution of a wide range of insurance products in many countries, banks and insurance companies need to make significant efforts to retain existing customers and maintain established relationships in today's environment (rapid change in consumer needs, the impact of the COVID-19 pandemic). languages. In view of the above, digitalization should be highlighted among the main drivers of bancassurance development. The development of digital bancassurance will improve the quality of customer service and provide competitive advantages 
to insurers and banks along with other new distribution channels (e.g., online platforms, etc.). According to some reports, it is believed that Francewill bethe leader in digital bancassurance. The French market will cover 9 billion eurosby 2023, and more than 24 billion euros - by 2028 [3].

In addition to the abovementioned, the drivers of bancassurance include the aging of the population (significant opportunities for the sale of pension products via bancassurance) [4] and the availability of tax benefits (in many countries, life insurance products and pension insurance have tax benefits, which makes these products attractive to customers), etc.

\section{References:}

1. Distribution channels. Retrieved from: https://www.insuranceeurope.eu/ insurancedata

2. Prykaziuk N.V. (2017). Strakhova systema Ukrajiny: teorija, metodologhija, prktyka: monoghrafija [Insurance system of Ukraine: theory, methodology, practice: monograph]. K.: Logos. (in Ukrainian)

3. Bancassurance Potential Analysis. Retrieved from: https://www.the-digitalinsurer.com/wp-content/uploads/2019/04/1478-Friendsurance_Press_Release_DBAPotential.pdf

4. 2020 Foresight: Bancassurance. Retrieved from: https://www.marketresearch.com/ product/sample-7466381.pdf 